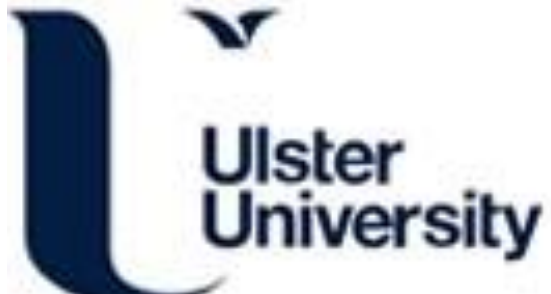

\section{An examination of student and provider perceptions of voluntary sector social work placements in Northern Ireland}

Mac Dermott, D., \& Campbell, A. (Accepted/In press). An examination of student and provider perceptions of voluntary sector social work placements in Northern Ireland. Journal of Social Work Education, 35(1), 31-49. https://doi.org/10.1080/02615479.2015.1100289

Link to publication record in Ulster University Research Portal

Published in:

Journal of Social Work Education

Publication Status:

Accepted/In press: 21/09/2015

DOI:

10.1080/02615479.2015.1100289

\section{Document Version}

Publisher's PDF, also known as Version of record

\section{General rights}

Copyright for the publications made accessible via Ulster University's Research Portal is retained by the author(s) and / or other copyright owners and it is a condition of accessing these publications that users recognise and abide by the legal requirements associated with these rights.

\section{Take down policy}

The Research Portal is Ulster University's institutional repository that provides access to Ulster's research outputs. Every effort has been made to ensure that content in the Research Portal does not infringe any person's rights, or applicable UK laws. If you discover content in the Research Portal that you believe breaches copyright or violates any law, please contact pure-support@ulster.ac.uk. 


\section{An examination of student and provider perceptions of voluntary sector social work placements in Northern Ireland}

\section{Denise Mac Dermott \& Anne Campbell}

To cite this article: Denise Mac Dermott \& Anne Campbell (2016) An examination of student and provider perceptions of voluntary sector social work placements in Northern Ireland, Social Work Education, 35:1, 31-49, DOI: 10.1080/02615479.2015.1100289

To link to this article: http://dx.doi.org/10.1080/02615479.2015.1100289

曲 Published online: 05 Nov 2015.

Submit your article to this journal $₫$

Џll Article views: 165

Q View related articles $\longleftarrow$

View Crossmark data $\nearrow$ 


\title{
An examination of student and provider perceptions of voluntary sector social work placements in Northern Ireland
}

\author{
Denise Mac Dermott ${ }^{\mathrm{a}}$ and Anne Campbell ${ }^{\mathrm{b}}$ \\ aDepartment of Social Work, Ulster University, Derry, UK; ${ }^{b}$ Department of Social Work, QUB, Belfast, UK
}

\begin{abstract}
Practice based learning in Northern Ireland is a core element of social work education and comprising $50 \%$ of the degree programme for undergraduate and postgraduate students. This article presents evidence about the perceptions of practice learning from voluntary sector/non-government organisation (NGO) placement providers and final year social work students on social work degree programmes in Northern Ireland in 2011. It draws on data from 121 respondents from 189 final year students and focus group interviews with voluntary sector providers offering $16 \%(85)$ of the total placements available to students. The agencies who participated in the research study provide a total of 55 PLOs to social work students, and are therefore fairly representative in terms of voluntary sector (NGO) provision. The article locates these data in the context of practice learning pedagogy and the changes introduced by the Regional Strategy for Practice Learning Provision in Northern Ireland 2010-2015. Several themes emerged including; induction, support and guidance, practice educator/ student relationship, professional identity and confidence in risk assessment and decision-making. Social work educators, placement providers and employers must be cognisant of newly qualified social workers' needs in terms of consolidating knowledge within the formative stages of their professional development.
\end{abstract}

\section{ARTICLE HISTORY}

Received 19 December 2014 Accepted 21 September 2015

\section{KEY WORDS}

Practice placement; social work education; practice learning; voluntary sector social work placements; field education

\section{Introduction}

Practice based learning is a central tenet in contemporary social work practice; it is recognised and acknowledged internationally as the signature pedagogy of the social work profession (Fortune, McCarthy, \& Abramson, 2001; Shulman, 2005; Wayne, Bogo, \& Raskin, 2010). Shulman (2005, p. 52) identifies signature pedagogies as 'the types of teaching that organise the fundamental ways in which future practitioners are educated for their new professions'. Early references to field education within social work practice are founded within the apprenticeship model. Students learn the mastery of social work by observing and modelling the techniques of their experienced, qualified supervisor. Mumm (2006, p. 74) comments that 'students learn best by practicing the skills, second best by having 
the skills demonstrated for them and the least effective ways are lecture and discussion' In short, students scaffold their learning and development as social work practitioners through direct experience. Practice learning opportunity (PLO) is the term used in the UK to describe student's experience of working directly with individuals, families, carers, groups and communities during their professional training. International colleagues will be more familiar with terms such as field education and field practicum. However, for the purposes of this article the researcher will use the term practice learning.

\section{Context}

Adult learning theory (Gardner, 1983; Kolb, 1984) provides the contextual nature of practice learning. Students in field education placements must become active participants in their learning. As developing practitioners, students need to 'construct' new knowledge for self, to learn professional skills through practice in social work settings. It is through this experiential learning that students develop skills of self-reflection, critical decision-making, understanding the theoretical concepts of intervention and demonstrating critical application of knowledge in direct work with service users and carers. Teater (2011) concurs it is by doing that students learn best. This requires a learning environment created by practice educators whereby students can achieve the learning outcomes, simultaneously learning about the circumstances of others in order to engage with them effectively and to learn about self, values, intrinsic motivations, defences and prejudices (Ruch, 2000).

A polarised view of what is and what is not social work is unhelpful and serves only to restrict the rich diversity of social work roles which exist and the transferability of skills and knowledge that occurs. The international and historical perspectives of social work champion its richness and diversity and add to the profession's identity which is not confined by welfare state provision (Bellinger, 2010).

Often in practice learning there is an over reliance on bureaucratic agency documentation, checklists and tick boxes. Munro (2005) argues that this is an area of conflict for practitioners and educators arising from managerial directives between actual time spent with families and completing paperwork. Fortune, Lee, and Cavazos (2007, p. 258) tested an assumption of social work field education that more frequent use of professional skills is associated with better outcomes for students. They concluded

Students who practiced professional skills more often during their field practicum reported themselves more competent in the areas they were practicing.

Social work education in Northern Ireland continues to provide a unique learning environment for students, offering the opportunity to learn to practise in an inter-professional and social services multi-disciplinary structure; including the opportunity to learn how to work with individuals, families, groups and communities in an emerging post conflict society. The introduction on the Degree in 2004 coincided with Northern Ireland emerging as a post conflict society. This resulted in a mandatory requirement for students to address issues associated with the conflict, more commonly known as the 'Troubles'. The NISCC in its Framework Specification for the Degree in Social Work (2003a) stipulated that 'the impact of past and current violence, conflict and divisions in Northern Irish society requires particular emphasis in the education and training of social work students in Northern Ireland.' (NISCC, 2003b, p. 6). This is included in the revised Framework Specification 
for the Degree in Social Work (2014a) understanding the contested nature of social work within the Northern Ireland context is a unique requirement for students completing their Degree in Northern Ireland.

Following the introduction of the NISCC Standards for Practice Learning for the Degree in Social Work (2006), (revised, 2009a) statutory, voluntary and independent social work agencies were required to obtain their Designated Practice Learning Provider status to contribute to practice learning provision for social work students (DPLP is a quality assurance and governance framework for field education in Northern Ireland). Part 3 of the Standards are specific to practice learning providers for the Degree in social work ensuring practice learning is robustly quality assured at an organisational level audited by the NISCC. 'The Standards are designed to promote quality and consistency in practice learning provision yet to be flexible enough to allow for continued innovation, improvement and development of practice learning within the work place.' (NISCC, 2006, p. 2).

This marked the beginning of a major review implementing significant changes to the context of social work training and education in Northern Ireland. There has been a concomitant increase in the academic demands on students, the phasing in of a new post qualifying framework for practitioners and the implementation and monitoring of the Designated Practice Learning Provider Scheme. The introduction of an honours degree provided professional education and training for social workers employed within statutory health and social services, education welfare, criminal justice, and in the wider voluntary sector (NGOs). Provision of care remains a major responsibility for social workers; with protection, control and rehabilitation integral components of contemporary social work practice. On successful attainment of the degree, social work graduates wishing to practise in Northern Ireland must be registered with NISCC, to successfully complete an Assessed Year in Employment (AYE). This process is specific to social work practitioners in Northern Ireland with AYE linked to registration, different systems operate in England, Scotland and Wales.

From 2009 the new Degree has been periodically reviewed every five years to ensure it is 'fit for purpose' by the Northern Ireland Social Care Council. In 2009 the findings identified an adequate supply of practice learning opportunities; however, the quality of these was variable. The Strategy was informed by the Review of the Degree in Social Work (2009b) alongside statistical returns from DPLPs to NISCC. Several key aims were identified, particularly the increase in the number of childcare placements and the wider geographical spread of placements throughout Northern Ireland where students have access to qualified social workers. The voluntary (NGO) sector currently provides $16 \%$ of student placements in Northern Ireland.

The first social work strategy for Northern Ireland was published Improving and Safeguarding Social Wellbeing: A Strategy for Social Work in Northern Ireland 2012-2022, which sets out the strategic 'roadmap' for the next ten years. In addition, Transforming Your Care: A Review of Health and Social Care in Northern Ireland (DHSSPSNI ,2011), sets out the significant changes to health and social care models of service delivery. These substantial policy drivers will have significant impact in the recruitment, training, supervision and continued professional development of newly qualified social workers (NQSWs) in Northern Ireland.

Subsequently, the 'Readiness to Practise Report' (NISCC, 2013) identified several areas to be considered within the second periodic review of the degree in social work. These include increase service user/carer involvement, recruitment and selection processes and 
increased student access to comprehensive information on PLOs in the voluntary sector including employability and access to AYE and post qualifying frameworks. The second periodic review of the degree (2014b) highlighted the progress made by DPLPs towards implementing the Regional Strategy for Practice Learning.

Across the UK the social work profession is undergoing significant reform including the role of practice learning in preparing NQWSs for their professional role. In England non-traditional placements are under threat as the focus is steered towards provision of statutory placements. In Wales one placement must be with a local authority social services department. Recent publications (Croisdale-Appleby Review, 2014; Narey Report, 2014) have highlighted the disparity within social work education, whilst offering different recommendations on future proofing the profession. Whilst Narey (2014) proposed the introduction of specialist qualifications for undergraduates wanting to practise within children's services, Croisdale-Appleby (2014) favours the retention of a generic qualification for entry to the profession.

It is therefore timely to take stock of practice based learning in the voluntary (NGO) sector, to identify and explore social work students and practice learning providers' perceptions of the voluntary sectors' contribution to professional social work education and training in Northern Ireland.

Therefore, the aims and objectives of the research were as follows:

To examine current student perceptions of voluntary sector Designated Practice Learning Provision in Northern Ireland.

To ascertain the views of practice learning providers in relation to practice learning provision for final year students on two social work degree programmes in Northern Ireland.

\section{Research design and methodology}

This research utilised a mixed methods approach utilising a quantitative student survey and a qualitative focus group and telephone interviews with placement practice learning staff to gather information from social work students and practice teachers.

\section{Student survey}

A structured questionnaire was distributed to final year students completing a social work degree at University of Ulster, Magee Campus and Queens University, Belfast. This cohort of students provided the total number of social work students proceeding to graduation in Northern Ireland in 2011. The questionnaire was distributed to the students by the researcher on their final recall day for the BSW Degree programme. (Bell, 2006, p.134) concurs 'There are distinct advantages in being able to distribute questionnaires to subjects personally. You can explain the purpose of the study and in some cases questionnaires can be completed on the spot.'

The researcher obtained permission to access final year students on their post placement debrief session at both universities. The choice of 'event sampling' was based on the work of Lucas (1997) who achieved a very high response rate from students when questionnaires were issued, completed and collected at the end of a specific class. The students were the primary sample within the research and using event sampling offered an optimum response rate. This approach was used in this study and produced a sample size of 121 students out 
of a total of 189 students who were proceeding to graduation having completed their professional social work training. The sample returned a response rate of $64 \%$.

Drawing on the literature (Bryman, 2004; Sarantakos, 2005), the questionnaire consisted of 'pre-coded' and fixed alternative questions using measurement at nominal and ordinal levels. Likert scale questions were used to gauge the strength of opinion on each of the identified areas. The use of a self-completing questionnaire was viewed as the most appropriate method as it was quicker to administer than postal questionnaires and eliminated the possible contamination effects of an interviewer.

\section{Focus group and telephone interviews with practice placement personnel}

Focus groups were used as an addendum and for the purposes of triangulation. It was anticipated this approach would offer rich narrative data capturing the subjective realities of key practice learning staff. The Northern Ireland Social Care Council Statistical Return (April 2011) was used to identify eight voluntary sector agencies who provided 73 practice learning opportunities out of a total of 85 during the academic year 2010-2011. The employing organisation of the author was one of these agencies and was therefore excluded.

Practice learning placement personnel from the seven voluntary sector agencies (NGOs) were originally invited to attend a focus group. In an effort to promote and secure participation the focus group was held in a central location to minimise participant's travel time. As focus groups create a process of sharing and comparing information among participants, two pre-requisites were applied as the inclusion criteria. Participants were required to have an understanding of the Regional Strategy for Practice Learning Provision in Northern Ireland (2010-2015) and to have been involved either directly or in the planning of practice learning/field practicum opportunities within their agency.

The primary limitation of using a focus group was that the initial rate of non-return was high with only four out of a total of seven agencies able to participate in the scheduled focus group. A total of seven individuals participated in the focus group. This resulted in additional data collection as a further three agencies requested a telephone interview to enable their agency contribution to be included in the final research. The request for telephone interviews presented a challenge to the researcher in terms of condensing a $90 \mathrm{~min}$ focus group session into a 30 min telephone interview. Telephone interviews were not factored into the original research protocol or costing, however, they were deemed essential to increase the non-return rate and deliver general themes of voluntary sector DPLPs in Northern Ireland. Whilst the numbers involved in the focus group and additional telephone interviews were small, results provided some insight into the opportunities and challenges facing the voluntary sector (NGOs) in relation to the provision of practice learning/ field education opportunities.

The voluntary sector currently provides $16 \%$ (85) of practice learning opportunities available to Northern Ireland social work students. This is provided across 19 DPLPs who are registered with NISCC. It must be noted that some agencies, although registered, are not offering practice learning opportunities to students. In total seven Designated Practice Learning Providers were represented in the qualitative element of the research. 


\section{Ethical issues}

This research was undertaken by a field work educator and an academic. The rationale was the introduction of the Regional Strategy for Practice Learning Provision in Northern Ireland 2010-2015. The researchers are involved in contributing to direct teaching and the provision of practice learning opportunities in Northern Ireland. A submission was approved by the University of Ulster Filter Ethics Committee in March 2011. Key ethical themes were subsequently addressed within the consent forms, participant information and questionnaire design which included 'voluntary participation', 'confidentiality', 'informed consent', 'privacy' and 'anonymity'.

To ensure confidentiality in the return of the survey, envelopes were provided with the student questionnaires and once completed they could be sealed and deposited in a returns box. Furthermore, in an effort to recognise and minimise potential bias, the researcher employed an independent facilitator to moderate the focus group session. Fowler (2009, p. 116) comments 'the independent facilitators' role will be to stimulate discussion and this will occur through a series of warm up questions moving towards specific thematic prompts.'

\section{Data analysis}

The data collected from the self-completing student questionnaire was analysed via the SPSS 17 computer package. Subsequently, the data-set was checked and 'cleaned' for errors and anomalies. A series of frequency tables and a number of descriptive statistics were generated from the data and are presented in table and bar chart formats within the findings section below.

Burnard (1991) offers a stage by stage process for analysing qualitative data, devising a method of thematic content analysis adapted from the grounded theory approach of Glaser and Strauss (1967). The method utilised had multiple stages which began with an open coding process, moving on to developing higher order themes. After a lengthy process of refinement, a final list of themes and common issues was produced, and in some instances, differences across the focus group participants. A similar method was adopted for the coding and categorising process with the telephone interviews In order to ensure at least face validity, transcripts were read by an independent researcher to identify similarities and dissimilarities in the categorisation process.

\section{Findings}

Quantitative and Qualitative data are presented within this section. Quantitative data are presented as descriptive statistics and via the reporting of valid percentages which were of specific interest to the research study.

\section{Profile of questionnaire respondents}

Of the total number of respondents $(n=121), 54 \%$ were from the 3 year undergraduate route and a further $26 \%$ from the 2 year accelerated route. In addition, $20 \%$ of respondents were from the trainee employment based route. The gender of respondents reflected the gender balance of students on the degree programme, with $85 \%$ female and $12 \%$ male respondents. $3 \%$ of respondents did not report their gender. In terms of the characteristics 
of the sample, the age categories of the respondents ranged from 20 to 46 years. The mean age for respondents was 28.3 years.

\section{Respondents prior work experience}

Seventy-four percent of respondents reported having prior experience of paid or unpaid social care work before commencing their professional training. The greatest majority, 38\% spent between 1 and 5 years in the social care sector and this is reflective of the general intake to the programme on a yearly basis. However, it is slightly more unusual for $18 \%$ of the cohort to have spent 6 or more years in the social care sector and this is usually a figure more indicative of the part time undergraduates in the social work programme.

Twenty-six percent did not respond to the question on paid or unpaid social care experience (Table 1).

\section{Practice learning opportunities: service user group}

Respondents were asked to report on the service user groups in which they worked for both field practicum/placement opportunities (PLOs). Service users groups are defined by the agencies that provide PLOs. The definitions usually identify the primary service users, i.e. family and childcare is representative of the broad range of children and families provision ranging from statutory initial assessment teams to voluntary agencies such as Women's Aid. The findings are reported below in the bar chart. Forty-four percent of respondents reported a family and childcare first placement, whilst $43 \%$ had a family and childcare placement for their final placement. Mental Health placement remained unchanged with a total of $13 \%$ of respondents accessing this service user group for first and final placement. The students must undertake a placement in family and childcare in either the first or second placement which may be within the voluntary or statutory sector. Adult care placements are primarily based in mental health and older people settings with outliers in education welfare and criminal justice sectors (Figure 1).

Table 2 illustrates the placement experience of the respondents $74 \%$ reported accessing a statutory practice learning opportunity for their first PLO. This number increased to $83 \%$ for the final PLO. In contrast, $26 \%$ reported accessing a voluntary sector first PLO, a percentage figure which decreased to $17.4 \%$ for the final PLO. This is a trend which does not fluctuate on a yearly basis, primarily because the majority of placements are based and resourced within the statutory sector in Northern Ireland.

Table 1. Time spent in employment.

\begin{tabular}{lcc}
\hline Time spent in employment & Frequency & Percent \\
\hline Less than 6 months & 7 & 5.8 \\
6 months-1 year & 15 & 12.4 \\
$1-2$ years & 16 & 13.2 \\
$2-3$ years & 16 & 13.2 \\
$4-5$ years & 14 & 11.4 \\
6 years + & 22 & 18.2 \\
Total & 90 & 74.4 \\
Missing & 31 & 25.6 \\
Total & 121 & 100.0 \\
\hline
\end{tabular}




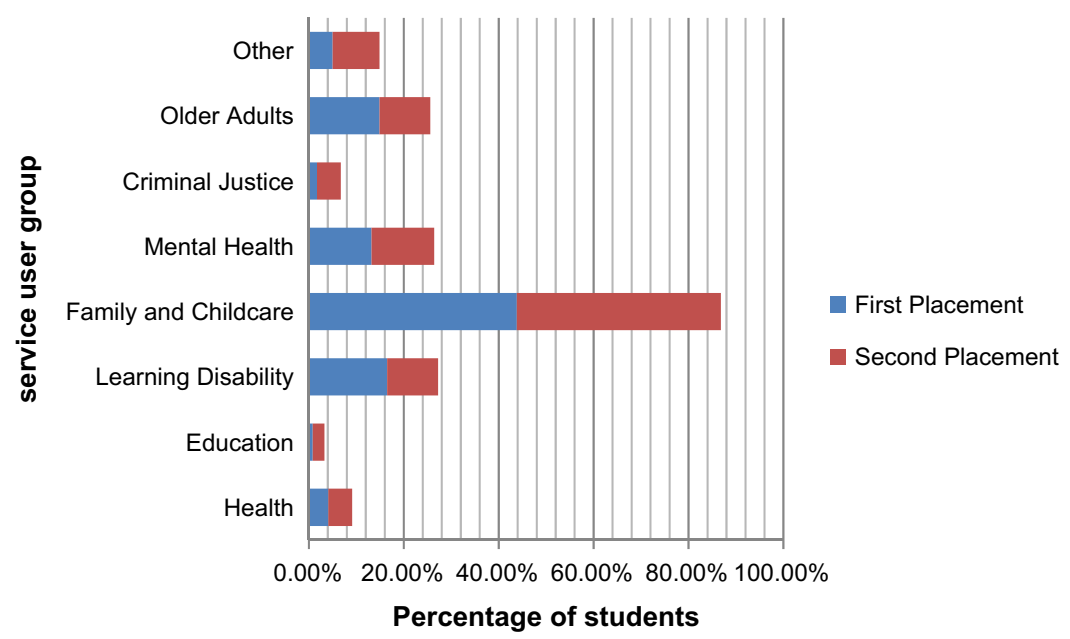

Figure 1. Service user groups.

Table 2. Statutory and voluntary placements.

\begin{tabular}{lcc}
\hline Host placement agency & First placement (\%) & Second placement (\%) \\
\hline Statutory & 74.4 & 82.6 \\
Voluntary (NGO) & 25.6 & 17.4 \\
\hline
\end{tabular}

\section{The practice learning experience}

Respondents were asked to report on their perceptions of the practice learning experience during the degree programme. This included satisfaction with student/ practice teacher relationships, focusing on communication, supervision and practice teacher feedback.

\section{Student relationship with practice teacher}

A primary element within the PLO is the respondent's relationship with their practice teacher. Practice teachers act as 'gatekeepers' to the social work profession and are tasked with assessing the competence of the student and whether or not they are 'fit for practice'. In Northern Ireland practice teachers are qualified social workers who complete specialist post qualifying training to supervise students. Therefore respondents were asked to report on their perceptions of the student/practice teacher relationship.

Eighty-eight percent of respondents reported the student/practice teacher relationship on PLO 1 as either 'extremely important' or 'highly important'. There was a slight increase reported for PLO 2 with $91 \%$ of respondents, identifying their relationship with their practice teacher as either 'extremely important' or 'highly important'.

Respondents were also asked to report their overall satisfaction with practice teacher supervision for the duration of their practice learning experience. For PLO 1, 73\% of respondents were 'very satisfied' or 'satisfied' and $14 \%$ of respondents stated they were 'very dissatisfied' or 'dissatisfied. There was a marked increase in the satisfaction rates of respondents for PLO 2, with 83\% reporting being 'very satisfied' or 'satisfied' with practice teacher supervision. Nine percent of respondents reported being 'very dissatisfied' or 'dissatisfied'. 
In addition, $86 \%$ of respondents reported 'strongly agree' or 'agree; that professional identity is enhanced through access to professional role models.

It was also felt that it was important to get a sense of the respondents' views on voluntary sector social work, irrespective of whether or not they had practice learning experience of the voluntary sector. In relation to whether voluntary sector PLOs were viewed as a positive environment for developing social work skills, $74 \%$ of respondents, recorded an answer of 'strongly agree' and 'agree', whilst, 3\% reported an answer of 'disagree'.

Figure 2 below captures the respondents' perceptions of voluntary sector social work practice learning placements in developing social work skills. It is clear from the graph that almost $74 \%$ of respondents agreed that voluntary sector PLOs provided a good environment for learning social work skills. This was mirrored in the qualitative commentary below which specifically highlighted that it encouraged new methods of working and creative approaches to practice.

Respondents were also asked whether there was an emphasis on statutory social work throughout their professional training. In response, $74 \%$ of respondents reported 'strongly agree' or 'agree' to this statement. Twelve percent of respondents answered 'strongly disagree' or 'disagree'. Respondents were asked whether it was necessary for NQSW s to have voluntary sector practice knowledge with $83 \%$ of respondents agreeing. Furthermore, respondents were asked to respond to the statement that 'voluntary sector PLOs are NOT beneficial to their professional training. Sixty-five percent of respondents answered 'strongly disagree' or 'disagree' with the statement. Eight percent of respondents answered 'strongly agreed' or 'agreed' to this statement.

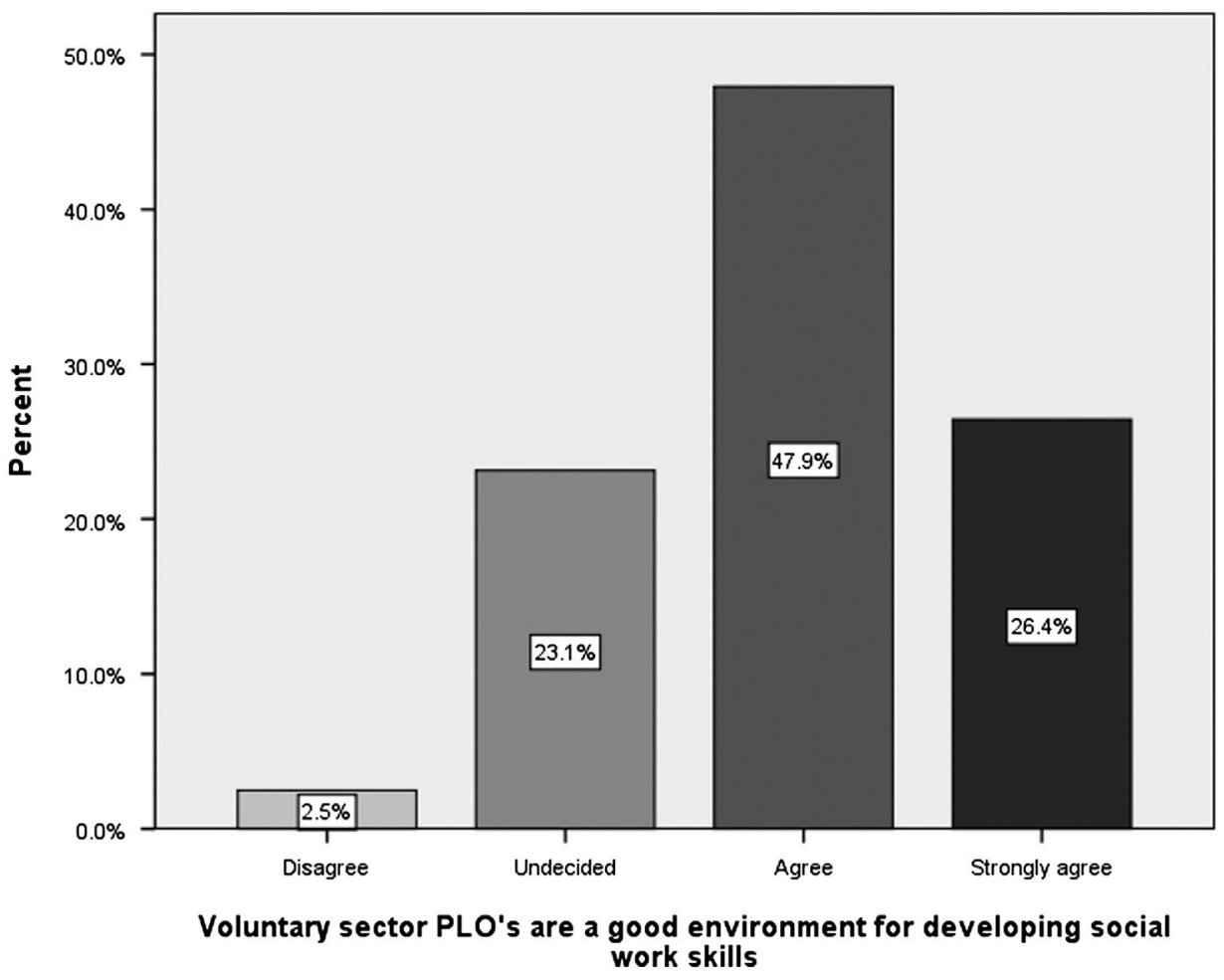

Figure 2. Student perceptions of voluntary sector PLO's in developing social work skills. 
Table 3. Do student social workers have more influence in a statutory role?

\begin{tabular}{lcc}
\hline Responses & Frequency & Percent \\
\hline Strongly disagree & 8 & 6.6 \\
Disagree & 30 & 24.8 \\
Undecided & 38 & 31.4 \\
Agree & 22 & 18.2 \\
Strongly agree & 23 & 19.0 \\
Total & 121 & 100 \\
\hline
\end{tabular}

One aspect of the research examined the perception of influence as determined by the statutory or voluntary role of the social worker. Respondents were asked to report whether or not they had more influence in a statutory role (Table 3 ).

Thirty-seven percent of respondents recorded an answer of 'strongly agree' and 'agree', whilst the response for 'strongly disagree' and 'disagree' was 31\%. Likewise, the same percentage, $31 \%$ were undecided which indicates that there is still a high level of student apprehension about the influence of the voluntary sector social worker role in practice.

Using thematic analysis (Burnard, 1991) several emerging issues were identified from the placement providers' focus group discussions. This included agency perceptions of provision; retention of staff involved in practice based learning, support necessary to meet requirements of the strategy, workforce culture and development and the use of Associate Providers. (Associate Providers are NGOs which do not have the infrastructure to meet the requirements of Designated Practice Learning Provider Scheme independently and align their agencies with Designated Providers to provide a student placement). In this article two themes are included from the qualitative data which are presented below:

- Placement provider perceptions of final social work placement.

- Workforce culture and development.

\section{Agency perceptions of practice learning provision for final year social work students}

All placement providers outlined that the PLOs offered within their respective agencies offered potential students a well-supported, quality assured and 'holistic' experience of social work intervention. The induction process was identified as essential to welcome students to the agency and to ascertain a starting point for student's learning journey.

\section{One participant spoke about their agency induction programme}

We have quite a robust induction programme which incorporates training [child protection] and the roles and responsibilities housed within the placement experience.

Another discussed how their agency had developed a tiered induction programme dependent on the level of the PLO.

There is more emphasis on risk in the final placement, for their evidence, this can be difficult because in first placement students can arrive with the misconception that their work will not involve risk. Our core business is child protection, everything we do involves risk. 
Two participants discussed the ethos of continued professional development within their respective agencies. There was some discussion about how this encourages a learning culture in the agency and the importance of having a team/project committed to developing student's learning.

At the end of the day the placements are to ensure that the social workers for the future are well trained, and we all work to that, you want to produce students fit for practise, our commitment to social work learning and development is absolute.

Each of the participants acknowledged their agencies were committed to a multi-disciplinary approach to social work characterised by a range of integrated individual and family focussed service provision. There was a general consensus that the voluntary sector offered creativity and flexibility; particularly the sector's capacity to identify and implement new models of working.

the voluntary sector can offer an enhanced alternative 'hands on' social work placement experience for students whilst still adhering to the relevant standards envisaged in the Strategy.

Recognition of how students learn and concepts of adult learning theory were highlighted by a number of participants. The responsibility of practice teachers as gatekeepers was also highlighted.

Although students can look 'good' on paper, the reality on placement is very different. This has sometimes leaded to difficulties with students. The onus is very much on the practice teacher (practice educator) if anything goes wrong, or the student is failing. It's almost a reflection on you. It can be a stressful time for staff; they need additional support and the situation becomes resource intensive quickly...

All of the participants felt their respective agencies were supportive of providing, wherever possible and practicable, a quality placement experience for students.

\section{Workforce culture and development in Northern Ireland}

Participants discussed the perceptions of the voluntary sector as a viable employment option for NQSWs. Six participants agreed that the availability of opportunities was definitely improving although the process was hindered by the lack of attractiveness in pay scales and whether agencies can facilitate AYE requirement for newly qualified workers. Three of the respective agencies have solid AYE structures in place; where this is not the case the larger voluntary sector agencies are offering support and in some instances providing AYE supervision to sector colleagues who cannot facilitate the requirement internally.

We have witnessed a noticeable increase in experienced social workers [post AYE] applying for our advertised posts ... this makes it difficult for the ones coming through to secure anything permanent.

There was further discussion on the economic climate and especially the precarious nature of funding for the sector. Several participants acknowledged that roles that might otherwise be pitched at qualified social work staff are, owing to funding limitations, pitched outside the standard social work salary scales. Current experience suggests social work is identified as desirable rather than essential in the job description.

What I mean is that the world of social care does not always mean the need for a social work qualification; there are significant challenges for agencies in their capacity to contract with funders, more and more we are seeing a drive for NVQ qualifications instead. 
Some participants whose agencies are not dedicated social work agencies felt this highlighted the depth within the sector, promoting a more inclusive culture and recognising the many facets and responsibility involved in securing and promoting change.

The voluntary sector has a credible image with service users, working alongside communities, developing volunteering and mentoring programmes to build support at local levels.

Four participants discussed the perception of the voluntary sector from the student's perspective on placement. Some participants stated anecdotal evidence which suggests students can often be concerned with whether or not voluntary sector placements are 'really social work'. It was debated by some of the participants that essentially this perception emerges from the on-going debate in social work about the professionalism of the role and the protection of title.

One participant commented on their most recent student and a discussion they had about employment options after the Degree.

the student said to me ... we may be getting paid less than a social worker within the statutory agencies but we have a caseload that is manageable, we are getting the appropriate levels of support and supervision and access to completing our AYE.

Similarly one participant discussed student's perceptions of 'real social work' and how their agency was viewed as a viable employment option owing to the statutory element of its core business.

my agency shares similar 'powers' and responsibilities with statutory sector colleagues in terms of legislatively defined work with children and young people ... a number of former social work students have sought out and obtained post qualifying employment with us.

\section{Discussion}

In Northern Ireland social work education is being shaped and rebranded by changes in the political and social discourse. The Health and Social Care (Reform) Act (Northern Ireland) (2009) enforces Public Personal Involvement as a statutory requirement for all public health and social care organisations. The devolution of criminal justice and policing in Northern Ireland in 2010 has changed the political landscape resulting in a re-emergence of local level democratic accountability. To this end, the public including service users expect greater levels of control and choice within the design and delivery of services. Moreover, service user involvement is a strategic priority within DHSSPSNI (2006a, p. 21) Training Strategy for Personal Social Services. This requires employer and training providers to ensure that benchmarks underpinning qualifications are informed through engagement with service users and communities. This is stipulated in the DHSSPSNI $(2012$, p. 7) Social Work Strategy 'Social work has an important contribution to make in taking forward the reform agenda for health and social care, in particular, in promoting independence through the development of community based and person centred practices'.

The current reforms in social work education throughout the UK and the frameworks in which practice based learning is provided have highlighted that students' experiences differ significantly (Carpenter et al., 2011). Practice learning in Northern Ireland aims to offer students one statutory (within a Health and Social Care Trust) and one voluntary sector placement. This is largely achieved through robust regional partnership arrangements with employers, placement providers and HEIs. However, several students graduate having had 
two statutory practice learning placements. In contrast, Croisdale-Appleby (2014) identified an increase in voluntary sector placements and decrease in statutory provision as the current trend in England, despite the recent steer towards accessing local authority placements (Narey, 2014). Resourcing issues as a result of continuing austerity measures are identified as contributing factors alongside on going difficulties with the increased demand for, and available supply of, good quality practice learning opportunities.

In this study, it was interesting to note that $75 \%$ of student respondents agreed there was an emphasis on statutory social work throughout their professional training. This may be linked to current workforce planning and development figures recorded by DHSSPSNI (2010b, p.4) which state 'Of the 3,500 social workers employed within Health and Social Care approximately 47\% work in Children's Services, 32\% in Adult Services and the remainder in specialist and management roles'.

This notion was referred to in the literature reviewed. (Bellinger, 2010, p. 601) questions 'who owns social work?' and suggests that a profession defined by government or local authority practice, creates an environment where 'practice learning is constructed as a training ground for efficient employees ... Statutory agencies need newly qualified staff who can pick up a full and complex caseload'.

In the dyad of social work educators and social work employers there is dissonance between expectations and the realities for NQSWs. Sharpe, Morriarty, Manthorpe, and Hussein (2011, p. 30) summarise this point, 'employers seem to be looking for social workers who are functionally ready and need help to fulfil their tasks in the workplace, whereas educators are aiming more at providing students with a broad professional base of abilities and understanding to be built upon through practice experience and CPD over time'.

In reviewing the recent developments within social work education in Northern Ireland, the influence of the statutory employing bodies cannot be ignored. Pugh (2005) suggests that prescriptive managerialism has removed the social activist agenda and any evidence of radical social work from statutory social work provision. Within social work education regional committee membership comprises representatives from each of the Health and Social Care Trusts, with one representative for the voluntary sector. Representation is linked to outputs and funding quotas, which presents a challenge for the voluntary sector in terms of its involvement and contribution to the social work curriculum.

One might question where does the voluntary sector 'fit' with this new managerialism? Is the sector perceived as an 'alternative' to statutory social work and its legislative functioning? Murphy, Duggan, and Joseph (2012) identify 'individualism' as a characteristic of the current neo-liberal policy, with the focus on empowerment, involvement and participation. Will increased demands on the voluntary sector including a push to provide individualised social services further skew the identity of the sector? Many commentators suggest the struggle to define social work weakens its position amongst other health and social care professionals (Bellinger, 2010; Hugman, 2009; Jordan, 2001). Indeed, the importance of obtaining and maintaining the professionalism of social work is often located within welfare state agencies and the neo-liberal agenda of maintaining the status quo. Stepney (2006) suggests the capacity of social work as a progressive force has been eroded by the 'reshaping' and 'rebranding' of the profession from successive governments. This has led to claims that social work has lost its 'core identity' and within this, the origins of social justice and inclusion have become clouded by the mantle of professionalism. This resonates with the findings of Croisdale-Appleby (2014, p. 66). 
There is also a concern that an undue concentration on statutory training and procedural training will be at the expense of other equally important components of a social workers' education.

Moreover, Nixon and Muir (2006) suggest it is participation in professional tasks in practice that build students' sense of professional self-identity and enable students to begin to internalise the social work role and locate themselves within it.

In this study, student respondents provided their views on voluntary sector social work, irrespective of whether or not they had practice learning experience of the voluntary sector. Voluntary sector PLOs were viewed as positive and highlighted as a helpful environment for developing social work skills by the majority of the respondents. The reason for this may be located in the number of students $(74 \%)$ with prior experience of paid or unpaid social care work on commencing the honours degree. This sentiment is echoed in student's responses on whether it is necessary for NQSWs to have voluntary sector practice knowledge with $83 \%$ of respondents agreeing.

Practice learning is a central tenet in establishing a students' sense of professional identity. In this study, $37 \%$ of respondents perceived themselves as having more influence within a statutory social work role. Although tenuous, the connection between employment history of university lecturers and tutors might influence classroom based learning in relation to professional identity, particularly if academics' practice backgrounds are within the statutory sector. This may result in less provision of 'real life' examples of voluntary and community social work roles and practice wisdom within the environment where students begin to develop their initial perceptions of 'real social work'.

In this study, $86 \%$ of students agreed their professional identity was enhanced by access to professional role models. Scholar (2014) suggests that 'social workers share a professional identity that transcends organisational settings'. The influence of the students' placement experiences weighs heavily on their sense of professional identity as a social worker and distinctions are likely to occur owing to practice setting. For example, is the social work role clearly defined? Are social workers employed by the placement agency? The Social Work Strategy (DHSSPSNI, 2012, p. 4) identifies the vision for social work in Northern Ireland, 'Social workers will work to improve and safeguard the social wellbeing of individuals ... by promoting their independence, supporting their social inclusion and participation in society, empowering them to take control of their lives and helping them to keep safe'. The Strategy contains a framework for social work practice to support the delivery of the vision of social work in improving and safeguarding social wellbeing. The framework identifies five key social work roles, prevention, support, intervention, protection and control. All social work practitioners in Northern Ireland, irrespective of their work context will use elements of each role. This Strategy will make a significant contribution to defining professional social work. However, the challenge remains for NGOs is to explicitly locate their service provision within the framework.

Levy, Shlomo, and Itzhaky (2014) in the initial findings from their longitudinal study concur that perceptions of role, the perceptions other have and the field practice setting are central to the development of professional identity in social work students. The importance of the practice teacher/student relationship in determining professional identity is also significant. Wayne et al. (2010) identify this as the context for learning and a relationship that is expected to be supportive and challenging. Indeed, the supervisory relationship between practice teacher and student is used as a model for students' practice with service users. Davys and Beddoe (2009) suggest supervision has a critical role to play for both 
social work students and NQSWs in enabling them to develop their professional mastery through reflection on real life practice. However, 'on the ground' supervisory practice is becoming increasingly focused on the functional, with the focus on risk management (Noble \& Irwin, 2009).

Ferguson and Smith (2011) in their study of final year social work students in nontraditional placements in South Africa found that these placements offered students the opportunity to address and recognise that social and structural problems require individual, social and structural responses. Northern Ireland remains a divided society. The complexities of the Northern Ireland political landscape, the legacy of 'The Troubles' and the development of a new emerging post conflict society offer students in Northern Ireland a similarly challenging practice learning environment. Das, O Neill, and Pinkerton (2015, p. 4) suggest 'the issues of sectarianism and the period of "The Troubles" have had a particular impact on the development of professional social work in Northern Ireland'. Since the 1970s the voluntary sector and community development approaches to social work have often represented a vehicle for the attainment of social justice and organic community empowerment. However, Ferguson and Smith (2011, p. 994) suggest a challenge is presented in that 'NGOs with a very clearly defined remit laid down by their funders limited the students' scope for conducting independent assessments since "the problem" was already defined for them'.

\section{Implications for social work education in Northern Ireland}

The Social Work Strategy for Northern Ireland (DHSSPSNI, 2012), identified social workers in the voluntary sector as being in a prime position to support people to participate in decisions affecting their lives, and to work towards influencing the shape and direction of service provision and policy-making in social work. Using community development approaches and working together with and within the voluntary sector organisations, social workers can help to empower communities through the use of community development approaches and help people to promote their rights, challenge inequalities and improve local communities. This is consistent with Transforming Your Care (2011) where the theme of empowering individuals, families and communities to get involved in promoting their own health and wellbeing is a key component of the revised model of service delivery in health and social care.

In this study, however, the response from Designated Practice Learning Providers highlighted the stark realities for NQSWs seeking employment within the voluntary (NGO) sector. Often a social work qualification is identified as desirable rather than essential criteria within the job descriptions of advertised posts. This, in turn, had an impact on voluntary sector agencies' capacity to attract NQSWs into the sector as a viable employment pathway. Additionally, cuts to the Northern Ireland Health and Social Care budget have resulted in some Health Trusts issuing a moratorium on recruitment. These challenges may result in HEIs in Northern Ireland producing highly skilled social work graduates for export to external labour markets. Although there is some evidence of change, In May 2014 revised guidance on completing AYE was issued by the NISCC, identifying a suitable post as a post that includes a social work qualification in the essential or desirable criteria. This has been a significant boost to students' perceptions of NGOs credibility and professional status. However, this may be a case of 'shifting sands' as the challenges that AYE initially presented for some voluntary sector employers have been remedied by the revised guidance, to an 
extent the challenge is shifting for voluntary sector employers from recruitment to retention of graduates post AYE. There remains disparity in remuneration packages between employing bodies in the statutory and voluntary sectors. In statutory social work employment the completion of AYE is linked to a change in salary band. The voluntary sector is unable to provide this incentive. Anecdotal evidence from voluntary sector employers indicates that many NQSWs are completing their AYE with them and moving into statutory employment. In February 2015 NISCC presented results on where social workers are undertaking their AYE in Northern Ireland.

\begin{tabular}{lccc}
\hline Organisation & $\begin{array}{l}\text { Temporary contract } \\
\text { via agency }\end{array}$ & $\begin{array}{l}\text { Permanent contract health and } \\
\text { social care trust }\end{array}$ & Total \\
\hline Belfast Health \& Social Care Trust & 4 & 19 & 23 \\
Northern Health \& Social Care Trust & 5 & 55 & 60 \\
South Eastern Health \& Social Care Trust & 7 & 25 & 32 \\
Southern Health \& Social Care Trust & 0 & 9 & 9 \\
Western Health \& Social Care Trust & 18 & 60 & 78 \\
Voluntary Sector & - & - & 70 \\
\hline
\end{tabular}

Source: Houston (2015).

There is ongoing debate regarding the experiences of NQSWs and their perceived needs in terms of underpinning knowledge and practice learning experience. Welch, Lerpiniere, and Young (2014) examined statutory social work managers' views of NQSWs preparedness for practice in Scotland. Their study identified limitations in NQSWs capacity to assess risk to individuals, self and colleagues, to manage complexity and to engage in group work to promote individual development and independence. This resonates with a Northern Ireland study conducted by Wilson and Kelly (2010) analysing the strengths and limitations of social work education, which found that $16 \%$ of NQSWs did not feel competent in assessing and managing risk. In contrast, Carpenter et al. (2011) concluded that NQSWs in England, employed in children's services, without prior practice learning experience of statutory children's services, performed as well as those with experience, when assessed after their first year of post qualifying experience.

In this study, the Designated Practice Learning Providers acknowledged that as collective agencies they were committed to an inter-professional approach to social work characterised by a range of integrated and family focussed service delivery models. There was also recognition of the creative and flexible contribution the voluntary sector provides to practice based learning within social work education.

\section{Conclusion}

This article has explored social work students and placement providers' perceptions of voluntary sector (NGO) practice learning provision in Northern Ireland. Nixon and Muir (2006, p. 226) identify professional practice in social work as 'a complex set of activities which involve direct work with service users, and their families, as well as work with other professionals and agencies. A range of knowledge and skills are used with a firm value base which recognises diversity and oppression as key elements within society' To an extent, this research was about exploring whether voluntary sector placements were considered 'less professional' and limiting to the development of students' professional identity. However, the findings suggest there is little evidence to support this assertion. The issues identified 
reflect those found in earlier research, suggesting that voluntary sector and non-traditional social work placements are valuable learning environments for students. The voluntary sector still remains marginalised in terms of its influence in areas of social work education and fieldwork practice. This resonates with Das et al. (2015, p. 14) commenting on community work as a method of practice in social work, 'Social work and its occupational spaces are developmental. In the current context, in Northern Ireland, there is a need to review social work's professionalism and create opportunities such that workers can share their knowledge with other social actors and build useful networks' The majority of students who participated in this research had prior experience before commencing the honours degree, gaining their experience as volunteers, youth workers, carers, service users, mentors or paid social care workers.

The challenge therefore to social work educators, placement providers and employers is to ensure that the value of voluntary sector and non-traditional placements is not lost within an ever narrowing view of what constitutes 'professional' social work. The voluntary sector requires support to attract NQSW s and this has been recognised by NISCC (2014). These placements can offer students opportunities to develop as critical and creative practitioners within inter-professional settings.

\section{References}

Bell, J. (2006). Doing your research project (4th ed.). Berkshire: Open University Press.

Bellinger, A. (2010). Studying the landscape: Practice learning for social work reconsidered. Social Work Education, 29, 599-615. doi:10.1080/02615470903508743

Bryman, A. (2004). Social research methods. Oxford: Oxford University Press.

Burnard, P. (1991). A method of analysing interview transcripts in qualitative research. Nurse Education Today, 11, 461-466. doi: 10.1016/0260-6917(91)90009-Y

Carpenter, J., Patsios, D., Wood, M., Shardlow, S., Blewett, J., Platt, D., ... Wong, C. (2011). Newly Qualified Social Worker Programme evaluation report on the second year (2009/10). Retrieved from http://www.bristol.ac.uk/sps/research/projects/current/rk7035/nqswyear2.

Croisdale-Appleby, D. (2014). Re-visioning social work education: An independent review. London: Department Of Health.

Das, C., O Neill, M., \& Pinkerton, J. (2015). Re-engaging with community work as a method of practice in social work: A view from Northern Ireland. Journal of Social Work, 1-20. doi:10.177/1468017315569644. first published online February 4, 2015.

Davys, A. M., \& Beddoe, L. (2009). The reflective learning model: Supervision of social work students. Social Work Education, 28, 919-933. doi:10.1080/02615470902748662

Department of Health and Personal Social Services (NI). (2006a). Personal Social Services Development and Training Strategy 2006-2016. Belfast: DHSSPSNI.

Department of Health and Personal Social Services (NI). (2010). Review of workforce planning for social services. Belfast: DHSSPSNI.

Department of Health and Personal Social Services (NI). (2011). Transforming your care: A review of health and social care in Northern Ireland. Belfast: DHSSPSNI.

Department of Health and Personal Social Services (NI). (2012). Improving and safeguarding social wellbeing: A strategy for social work in Northern Ireland 2012-2022. Belfast: DHSSPSNI.

Ferguson, I., \& Smith, L. (2011). Education for change: Student placements in campaigning organisations and social movements in South Africa. British Journal of Social Work, 42: 974-994. doi:10.1093/bjsw/bcr143

Fortune, A. E., McCarthy, M., \& Abramson, J. S. (2001). Student learning processes in field education: Relationships of learning activities to quality of field instruction, satisfaction and performance among MSW students. Journal of Social Work Education, 37, 111-124. 
Fortune, A. E., Lee, M., \& Calvazos, A. (2007). Does practice make perfect? The Clinical Supervisor, 26, 239-263. doi:10.1300/J001v26n01_15

Fowler, F. J. (2009). Survey research methods (4th ed.). Thousand Oaks, CA: Sage.

Gardner, H. (1983). Frames of mind: The theory of Multiple Intelligences. New York, NY: Basic Books. Glaser, B. G., \& Strauss, A. (1967). The discovery of grounded theory: Strategies for qualitative research. Chicago, IL: Aldine.

Houston, J. (2015, February). Assessed year in employment presentation to final year students. Presented at the Ulster University Employability Event, Derry.

Hugman, R. (2009). But is it social work? Some reflections on mistaken identities. British Journal of Social Work, 39, 1138-1153. doi:10.1093/bjsw/bcm158

Jordan, B. (2001). Tough love: Social work, social exclusion and the third way. British Journal of Social Work, 31, 527-546. doi:10.1093/bjsw/31.4.527

Kolb, D. A. (1984). Experiential learning: Experience as a source of learning and development. Englewood Cliffs, NJ: Prentice Hall.

Levy, D., Shlomo, S. B., \& Itzhaky, H. (2014). The building blocks of professional identity among social work graduates. Social Work Education, 33, 1-16. doi:10.1080/02615479.2014.883600

Lucas, R. (1997). Youth, gender and part-time work - Students in the labour process. Work, Employment and Society, 11, 595-614. doi:10.1177/0950017097112001

Mumm, A. (2006). Teaching social work students practice skills. Journal of Teaching in Social Work, 26, 71-89. doi:10.1300/J067v26n03_05.

Munro, E. (2005). A systems approach to investigating child abuse deaths. British Journal of Social Work, 35, 531-546. doi:10.1093/bjsw/bch194.

Murphy, D., Duggan, M., \& Joesph, S. (2012). Relationship-based social work and its compatability with the person-centred approach: Principled versus Instrumental Perspectives. British Journal of Social Work, 43, 1-17. doi:10.1093/bjsw/bcs003

Narey, M. (2014). Making the education of social workers consistently effective; Independent review of the education of children's social workers. London: Department of Education.

Nixon, S., \& Muir, A. (2006). Practice learning and the development of professional practice. Social Work Education, 25, 798-811.

Noble, C., \& Irwin, J. (2009). Social work supervision: An exploration of the current challenges in a rapidly changing social, economic and political environment. Journal of Social Work, 9, 345-358. doi: http://dx.doi.org/10.1177/1468017309334848

Northern Ireland Social Care Council. (2003a). Framework specification for the degree in social work. Belfast: NISCC.

Northern Ireland Social Care Council. (2003b). Practice learning requirements for the degree in social work. Belfast: NISCC.

Northern Ireland Social Care Council. (2006). The standards for practice learning for the degree in social work. Belfast: NISCC.

Northern Ireland Social Care Council. (2009a). The standards for practice learning for social workrevised. Belfast: NISCC.

Northern Ireland Social Care Council. (2009b). The five year periodic review of the degree in social work. Belfast: NISCC.

Northern Ireland Social Care Council. (2011). National occupational standards for social work. Belfast: NISCC.

Northern Ireland Social Care Council. (2013). Readiness to practise: A report from a study of new social work graduates' preparedness for practice: An analysis of the views of key stakeholders. Belfast: NISCC.

Northern Ireland Social Care Council (2014a). Framework specification for the degree in social work. Belfast: NISCC.

Northern Ireland Social Care Council. (2014b). The second periodic review of the degree in social work. Belfast: NISCC.

Pugh, R. (2005). The professionalisation of social work in the UK: Independence, prescription and regulation. Portularia, 5, 77-94.

Ruch, G. (2000). Self and social work: Towards an integrated model of learning. Journal of Social Work Practice, 14, 99-112. doi:10.1080/02650530020020500 
Sarantakos, S. (2005). Social research (3rd ed.). Hampshire: Palgrave Macmillan.

Scholar, H. (2014). Devaluing non-traditional social work placements is a loss to the profession. Retrieved from http://www.communitycare.co.uk/2014/08/18/devaluing-non-traditional-socialwork-placements-loss-profession/

Sharpe, E., Moriarty, J., Manthorpe, J., \& Hussein, S. (2011). Into the workforce. Interim report from a study funded under the Department of Health Social Care Workforce Research Initiative. London: Social Care Workforce Research Unit, King's College.

Shulman, L. S. (2005). Signature pedagogies in the professions. Daedalus, 134, 52-59.

Stepney, P. (2006). Mission impossible: Critical practice in social work. British Journal of Social Work, 36, 1289-1307. doi:10.1093/bjsw/bch388

Teater, B. (2011). Maximizing student learning: A case example of applying teaching and learning theory in social work education. Social Work Education: The International Journal, 30, 571-585. doi: http://dx.doi.org/10.1080/02615479.2010.505262

The Health and Social Care (Reform) Act (Northern Ireland) (2009).

Wayne, J., Bogo, M., \& Raskin, M. (2010). Field education as the signature pedagogy of social work education. Journal of Social Work Education, 46, 327-339. doi: http://dx.doi.org/10.5175/JSWE.2010.200900043

Welch, V., Lerpiniere, J., \& Young, E. (2014). Scottish first line manager's views of newly qualified social workers' preparedness for practice; findings from an online Delphi Study. Retrieved from http://www.celcis.org/media/resources/publications/Scottish_Line_Manager_Views_of_Newly_ Qualified_Social_Workers.pdf

Wilson, G., \& Kelly, B. (2010). Enhancing social work students' learning experience and readiness to undertake practice learning. Retrieved from http://www.swap.ac.uk/docs/projects/practice_ learning130710.pdf 